\title{
THE ATTITUDE OF THE PEOPLE'S REPUBLIC OF CHINA TOWARDS THE ANNEXATION OF CRIMEA BY THE RUSSIAN FEDERATION IN THE CONTEXT OF ATTACHMENT TO THE PRINCIPLES OF FOREIGN POLICY
}

\begin{abstract}
The aim of the article is to present and evaluate the attitude of the People's Republic of China towards the annexation of Crimea by the Russian Federation in the context of attachment to the foreign policy principles of the Middle Kingdom. The introduction shows Beijing's approach to the Five Principles of Peaceful Coexistence that are China's foreign policy doctrine. In the following parts was presented the reaction of the Chinese authorities to the annexation of Crimea by Russia and the most important circumstances conditioning it. The analysis was intended to answer the question whether Beijing's attitude during the Crimea crisis was a manifestation of embezzlement with the basic principles of the PRC's foreign policy? The answer to this question is positive. By annexing Crimea, Russia broke all the Five Principles of Peaceful Coexistence. Despite this, Pekin did not criticize it. On the contrary, it tried to justify Moscow's actions. During the crisis, Beijing wanted to achieve the greatest benefits and behaved according to a pragmatic approach, which is characteristic of the contemporary PRC's foreign policy. This confirmed that the Five Principles of Peaceful Coexistence are treated instrumentally by the Chinese authorities. When important circumstances speak for it, they are ready to dissent from these principles. This negatively affects the sincerity of Beijing's intentions on the international forum, and raises the question of its policy in the future, after China reaches a dominant position in the world.
\end{abstract}

Keywords: The People's Republic of China, annexation of Crimea, Russian Federation, principles of foreign policy, Five Principles of Peaceful Coexistence.

\section{INTRODUCTION - PRINCIPLES OF PRC FOREIGN POLICY}

In the year of the annexation of Crimea by Russia has passed 70 years since the wording of the Five Principles of Peaceful Coexistence by the leaders of the People's Republic of China which are the basic principles of the foreign policy of the Middle Kingdom. These principles are mutual respect for sovereignty and territorial integrity, mutual non-aggression, non-interference in each other's internal affairs, equality and mutual benefit, and peaceful coexistence (Nathan). The conceptualization and adhering to the above principles by Beijing for decades resulted from several key factors. First of all, China has for centuries

\footnotetext{
${ }^{1}$ Łukasz Jureńczyk, DSc PhD, university professor, Institute of Political Science, Kazimierz Wielki University in Bydgoszcz, J. Poniatowskiego 12 St., 85-001 Bydgoszcz; e-mail: lukaszjurenczyk@ukw.edu.pl. ORCID: 0000-0003-1149-925X.
} 
been the victim of external colonial interference, which has established its sense of humiliation in these activities. Second, Beijing aims to unite all lands considered Chinese and to preserve territorial integrity in the face of growing autonomous tendencies. Thirdly, competition for influence in individual countries between the USSR and the US caused the risk of another World War and at the same time limited the possibilities of China's international influencing. Fourthly, China promotes the concept of a multipolar world, thereby opposes to the US hegemony. American unilateralism poses a threat to China's security, and their interference in the internal affairs of states has a negative impact on the globalization of the interests of the PRC. Fifth, China is now one of the last constitutionally socialist states, and therefore it opposes the spread of democratic values by the West. The leaders of the Communist Party of China believe that each state should determine its own social and political system and the way of economic development. Sixth, China is creating itself as the leader of the developing world and promoting the concept of "South-South" cooperation. In contrast to the West, it is ready to cooperate with any political regime and tries to convince its partners that will not impose its beliefs on them.

The aim of the article is to present and evaluate the attitude of the People's Republic of China towards the annexation of Crimea by the Russian Federation in the context of attachment to the foreign policy principles of the Middle Kingdom. The main research problem is the answer to the question whether the attitude of China towards the Crimea crisis was a manifestation of misappropriation of the Principles of Peaceful Coexistence? The current administration of the PRC claims that China invariably acts internationally in line with these principles. China's attitude to the annexation of Crimea by Russia, however, denies this position. It can be assumed that the above principles are only of moral character. However, the PRC's foreign policy is not idealistic. On the contrary, it is highly pragmatic and conditioned by strategic determinants. It fits most into the paradigm of structural realism of an offensive type. Therefore, when strategic interests speak for it, Beijing is ready to betray these principles.

Most often, Beijing respects the Five Principles of Peaceful Coexistence, if the situation concerns remote regions, for which it has no significant geopolitical interests, going beyond standard economic cooperation. The further from China's borders, the easier it is for Beijing to combine the rhetoric of the above principles with promoting its own interests (Nathan). Referring to the above moral indications most often goes hand in hand with the interests of the PRC. For China, it is positive when other powers don't interfere with the internal affairs of states. This may lead to the consolidation of their influence at the expense of China. The interference with the use of military force is particularly harmful, because it can destabilize the region and hinder China's economic cooperation.

Beijing usually refers in its foreign policy to the Five Principles of Peaceful Coexistence. It does so even during internal conflicts that generate major humanitarian crises. In recent years, Beijing has blocked the decisive actions of the international community against dictators, for example during the crises in Kosovo, Sudan, Zimbabwe or Burma (Duggan, 2016). It should be emphasized that there was a wide-scale violation of human rights and even ethnic cleansing, war crimes or crimes against humanity. Therefore, it was justified to refer to the concept of "Responsibility to Protect" and conduct military operations to defend civilians residing in threatened areas. Although China formally supports the legitimacy of this concept, in practice it blocks the possibility of its implementation. The exception to this rule was Beijing's abstention during the adoption of resolution 1973, which sanctioned the introduction of a no-fly zone in Libya and the protection of civilians from the government 
forces of Muammar al-Gaddafi. Under the pressure of the countries of the region, China did not use a veto and thus allowed NATO to carry out air operation in that country. However, when Beijing saw that it was moving towards a change of the political regime, they began to criticize those activities (Junbo, Zhimin, 2016). Also the PRC's attitude towards the civil war in Syria was significant. Beijing praised the effectiveness of the bombings carried out by Russia, because they were executed with the consent of the Bashar al-Assad government. This was despite the fact that it did not focus on attacks against terrorist groups from the so-called Islamic State, but against forces of anti-government rebel groups. At the same time, only between 2011 and 2017, Beijing and Moscow vetoed six times UN Security Council resolutions on Syria. In this way, they opposed to the imposition of sanctions on the criminal regime of Syria, even when it used chemical weapons against civilians (Zhou, 2017). On the other hand, China did not agree on activities in Syria of anti-terrorist coalition under the US leadership. It was afraid that it would lead to the overthrow of the existing government and the emergence of new authorities favoring the USA and the West.

\section{RESPONSE OF THE PRC TO THE ANNEXATION OF CRIMEA BY RF}

Since the beginning of March, Russian soldiers in uniforms without emblems indicating their origin were illegally staying in the Crimea. They occupied or blocked Ukrainian military facilities (Macaskill, 2014). On 16 March 2014, a referendum was held on the territory of the Autonomous Republic of Crimea and Sevastopol. According to official results, $96.77 \%$ of voters were in favor of joining Russia. Two days later in the Kremlin, President Vladimir Putin signed an agreement with the chairman of the Verkhovna Rada of Crimea, Vladimir Konstantinov, prime minister of Crimea Sergey Aksyonov and mayor of Sevastopol Alexey Chaly on the entry of the Republic of Crimea and Sevastopol to the Russian Federation. The Chinese authorities have kept abstinence from this event. They abstained from criticism, even though it clearly undermined the Five Principles of Peaceful Coexistence. It was a consequence in relation to earlier events. During the disputes between Russia and Ukraine over the transmission of gas in 2006 and 2009, Chinese authorities and state media refrained from criticizing Moscow's actions, even though they undermined the sovereignty of Ukraine. Also, later hybrid attacks by Russia in Donbas were not openly criticized by Beijing. The Chinese authorities consistently presented a restrained and moderate attitude towards Russia's actions in Ukraine (Arduino, 2017). Beijing even tried to defend Moscow by pointing out that its policy was a consequence of the "historical prerequisites" existed between Russia and Ukraine. It also said that the West was partly responsible for the events in eastern Ukraine. This was the reference to the interference in the internal affairs of Ukraine, by supporting anti-Russian color revolutions (Lanteigne, 2016).

The Western powers tried to condemn the referendum in Crimea in the UN Security Council and its subsequent annexation by Russia. It was obvious, however, that these actions were blocked by a veto from Moscow. Beijing decided to refrain from voting on resolutions. Also during the vote on UN General Assembly resolution 68/262 on the territorial integrity of Ukraine and the Crimean crisis, China abstained. Beijing did not even issue an official statement regarding the work on resolutions on the Crimea in both UN bodies. When journalists asked a representative of China at the UN Li Baodong about the issue of Crimea, he replied: "We are paying very close attention to the situation in Ukraine" and "We hope all parties can calmly maintain restraint to prevent the situation from further escalating and worsening. Political resolution and dialogue is the only way out". (Reuters, 
2014) China did not decide to vote against its strategic partner, which is Russia (Junbo, Zhimin, 2016), but on the other hand it did not want to support it, because it would be an outright strikethrough of the Five Principles of Peaceful Coexistence. Pekin was also afraid that such action would mobilize separatist movements in China, mainly in Tibet and Xinjiang province, and contribute to consolidating the separateness of Taiwan. It also did not want the recognition by the international community of the annexation of Crimea to strengthen separatist movements in different parts of the world.

During the Crimean crisis, Beijing did not want to engage politically more significantly. In the conflict between Russia and Ukraine and the West Beijing was pretending to be a neutral observer. However, China was interested in avoiding the escalation of this conflict. Therefore, it opposed the economic sanctions imposed by the West on Russia. Beijing argued that such sanctions would be ineffective and would in no way bring the parties closer to resolving the crisis. China was most concerned about the intensification of military activity in Ukraine and possible military support to it by NATO states. Therefore, it wanted the conflict to be solved through diplomatic channels. For this reason, Beijing proposed a three-point de-escalation plan for the conflict. It postulated for the establishment of an international mechanism to reduce tensions, restraint of all parties to the conflict and focus on regional economic assistance (Lanteigne, 2016).

As previously mentioned, Beijing signaled an understanding of Russia's attitude towards Ukraine, pointing to its historic causes. This has made it easier for China to tighten political, economic and military relations with Russia. At the same time, Beijing expressed its willingness to maintain friendly cooperation with Ukraine as well. It tried to convince the authorities that it respected the independence, sovereignty and territorial integrity of this state (Reuters, 2014). Such an attitude can be regarded as a policy of evasion or a specific manifestation of hypocrisy or even diplomatic schizophrenia. In fact, China's attitude to Russia's actions in eastern Ukraine was one of the most serious violations of the Five Principles of Peaceful Coexistence. Beijing rejected the possibility of condemning Moscow for annexing Crimea and later supporting the rebel forces fighting in the Donbass (MacDonald, 2016). Thus, it undermined the sincerity of its intentions towards the international community and respect for the principles of sovereignty, independence, territorial integrity, equality of states, non-aggression and non-interference in internal affairs.

The symbolic presentation of a different approach of China and Western countries towards Russia's activities in Ukraine was the celebration of May 8, 2015 in Moscow, the 70th anniversary of the victory over Nazi Germany. For President Vladimir Putin, this was an opportunity to demonstrate Russia's strength by organizing a great military parade. The guest of honor of this ceremony was Chinese President Xi Jinping. The leaders of China and Russia together admired the display of individual elements of Russian military equipment. It could have been read as China's consent to Russia's militaristic policy towards Ukraine. In contrast to Beijing, Western leaders boycotted participation in the celebrations due to the Russian annexation of Crimea and military operations in Donbass (Tharoor, 2015).

\section{CIRCUMSTANCES OF THE ATTITUDE OF THE PRC TOWARDS THE ANNEXATION OF CRIMEA BY RF}

It should be emphasized that China has significantly benefited from the international consequences of the annexation of Crimea by Russia. First of all, it positively affected the 
position of the PRC in strategic rivalry with the USA. Russia's actions forced the United States to focus more on Eastern Europe. Washington has engaged in efforts to support the political and military reinforcement of NATO's eastern flank. This has, to some extent, diverted its attention from China's key East Asian region, particularly Southeast Asia, in which the PRC is trying to consolidate its influence. After the annexation of Crimea in the US security strategy and strategic documents of NATO, the destabilizing actions of Russia in Eastern Europe were described as the main strategic challenge for the West (MacDonald, 2016). Somehow it softened the "Pivot" to Asia announced in 2011 by President Barack Obama. It is worth noting that the attitude of Moscow and Beijing towards the West differs significantly. Despite the structural weaknesses and the limited development perspectives, the Russian authorities decided to pursue a tough policy, the main manifestation of which are actions towards Ukraine aspiring to the West. In this way, Russia wants to show that the West must reckon with it (Snetkov, 2017) and respect its sphere of influence. In practice, however, the deepening conflict with the West has accelerated the economic weakening of Russia. China presents a much more prudent and restrained attitude towards the West, including the US. Beijing realizes that the American turnaround towards Asia is primarily focused on stopping China's expansion. Nevertheless, the Chinese authorities have not reacted aggressively to the US policy of containment in the region (Kai, 2017).

It should be emphasized that China and Russia have a common strategic interest, which consists in counteracting the hegemony of the United States and the dominant NATO military position in the world. The Russian authorities see the growing power of the PRC, which is gradually starting to compete with the US for the role of the world leader. For Russia, it is important that, unlike in the United States, China is in favor of a multi-polar international environment. Russia is interested in influencing the formation of a new world order, which can be ensured by close cooperation with China. The Kremlin is convinced that with the world's leading role of China it will be able to gain a much better position for Russia than with the leadership of the West (Leichtova, 2016). Tensions between Russia and NATO caused by the annexation of Crimea encouraged Russia to work more closely with China on the defense issues. This mainly applies to joint sea exercises. In Russia's Black Sea port of Novorossiysk the joint command center for the exercises has been set up. On May 20, 2014, the third major joint naval exercises began - "Joint Sea Drill" 2014 in the East China Sea (Lin, Singer, 2014). The "Joint Sea Drill" exercises 2015 took place for the first time in the Mediterranean Sea, and "Joint Sea Drill" 2017 in the Baltic Sea (Higgins, 2017). This cooperation is clearly aimed at the domination of the United States and NATO in these waters. In recent years, the question of arms trade between Russia and China has changed significantly. For decades the USSR and later the Russian Federation was the main supplier of military equipment to the PRC. Currently, China practically no longer needs arms from Russia. It can copy virtually every Russian military equipment and has itself become an important arms exporter (Donaldson, Nogee, Nadkarni, 2015). Nevertheless, in March 2013, China ordered 24 Su-35 multi-role fighters and four submarines from Russia (Bitzinger, 2015). Despite the growing cooperation in the field of defense between China and Russia, it can't be assumed that these countries will establish a lasting military alliance. They are still competing with each other, which primarily concerns the Central Asia region. In addition, it is possible that growing in power, overpopulated and in needing of energy resources China will also have rising geopolitical aspirations for unpopulated and resourcerich Siberia and the Russian Far East (Black, 2015). 
Also in the economic area, China has become the main beneficiary of the Crimean crisis. The sanctions imposed on Russia by the West have significantly depleted the possibilities of its trade cooperation with the European Union and the United States. This forced Russia to intensify cooperation with other partners. The neighboring China has become a natural direction (Copper, 2016), with which in 2001 Russia signed an agreement on strategic partnership. In addition to the geographical proximity, a number of other factors speak in favor of the strengthening of economic relations. Above all, the PRC has significant budget surpluses that allow it to implement large-scale foreign investments. In addition, it is a dynamically developing economy in need of energy resources, which are in turn the main export commodity of Russia. Russia, in turn, is a large, absorptive market, which gives Chinese entrepreneurs significant export opportunities for industrial goods. Closer economic cooperation between countries, with a deepening difference in potentials and a specific resources-commodity structure of trade, means that Russia is beginning to be perceived as a "junior partner" of China (Copper, 2016).

The diversification of oil and gas supplies by the European Union countries resulted in a reduction of Russia's budget revenues. Moscow tried to quickly fill the deepening gap, which is why it was looking for other recipients, ready to make bigger negotiation concessions. Russia was particularly flexible towards the Chinese proposal to lower prices for energy imports and get access to upstream development projects. The most serious undertaking was signing a USD 400 billion worth, 30-year-contract between Gazprom and the China National Petroleum Corporation for the purchase of Siberian natural gas by China. Previously, the Siberia-Daqing project was unsuccessfully negotiated for 19 years. The Crimea crisis and Western sanctions against Russia led to a quick finalization of negotiations. China has also obtained permission for direct investments in Vankor oil and gas fields in eastern Siberia, as well as into the Arctic Yamal LNG project. Exploitation of new natural gas and crude oil deposits in eastern Siberia and the construction of gas and oil pipelines from Russia to China gives the prospect of long-term export of energy resources to the Middle Kingdom (Perovic, 2009). In May 2014, China and Moscow also signed a number of other agreements, including the areas of financial assistance, trade, infrastructure and agriculture. In the Memorandum of Understanding, Beijing pledged, among others, to grant a loan of USD 6 billion for the construction of high-speed railway (Arduino, 2017).

At the end of 2013, President Xi Jinping presented flagship international economic projects, i.e. "One Belt, One Road" initiative called "New Silk Road" and Asian Infrastructure Investment Bank. For Russia, these projects posed a risk of further strengthening of China's economic position in Asia, also at its cost. However, the conflict with the West caused that Russia supported both initiatives and expressed its willingness to join them (Wan, 2016). Moscow recognized that enhanced cooperation with China could be a panacea for deteriorating economic relations with the West. In addition, it considered that the proposed projects could lead to a weakening of the influence of Western countries in Asia, mainly the United States. This concerned both the land territory and the adjacent reservoirs, primarily the seas of the Indian Ocean (Chenoy, Kumar, 2017). China also proposed establishing a development bank for the Shanghai Cooperation Organization, which it has dominated. This proposal was particularly problematic for Russia, which was afraid of weakening its position in Central Asia. Russia, however, was aware that regardless of this project, rapidly growing China would still increase its influence in the region (Fernandes, 2014). The conflict with 
the West motivated Moscow to support this project (Chan, 2017), hoping that Beijing would respect the basic interests of Russia in Central Asia.

It is also worth looking at the problem of the annexation of Crimea in the context of the economic relations between China and Ukraine. In 2013, Ukraine became the new strategic economic partner of the PRC. For the USD 10 billion previously invested by China in Ukraine, Beijing proposed additional investments for the sum of USD 8 billion. Officially, these funds were to be used for the development of the Ukrainian economy. However, partners discussed the possibility of investment of Chinese companies in deep-water port on the Crimean Peninsula. It was to be an important transport point between China and Europe. China has also invested USD 2.6 billion in the agricultural sector in Ukraine to increase its productivity. The PRC wanted to become an important recipient of Ukrainian agricultural products. Contrary to appearances, the Crimean crisis did not threaten China's investments in Ukraine. This is due to the fact that Ukraine is now more in need of Chinese economic support as well as Beijing's mediation in the conflict with Moscow. In March 2015, China offered Ukraine another USD 15 billion in loans for housing. It also suggested the possibility of investing additional funds in the aviation and IT sectors. After the annexation of Crimea by Russia, trade between China and Ukraine also increased sharply, over a year by more than 50\% (Copper, 2016).

Despite numerous benefits, Russia's action in eastern Ukraine is problematic for China because it negatively affects the perception of the sincerity of its intentions in the international relations. Earlier, Beijing has repeatedly criticized the interference of the powers in the internal affairs of states (Lanteigne, 2016). During many internal conflicts, it preached its attachment to the Five Principles of Peaceful Coexistent in the United Nations. At the same time, China blocked the possibility of imposing sanctions on inhuman regimes, even though it could contribute to faster resolution of conflicts. On the other hand, Beijing did not decide to condemn Russia for violation of all the Five Principles of Peaceful Coexistent. The resulting awkwardness is also noticeable in regional cooperation, mainly within the framework of the Shanghai Cooperation Organization. In the Declaration of Dushanbe in 2000, member states influenced by China inscribed basis of cooperation based on respecting the internal policy of each state. They agreed that anyone could not interfere in the internal affairs of states, even under the pretext of humanitarian intervention or the protection of human rights. They also advocated respect for territorial integrity and peaceful resolution of conflicts. These rules have been repeated many times at the next SCO summits (Kiezkowa, 2016). During the Crimean crisis, China despised these principles, which further weakened the already fairly façade platform of cooperation.

\section{CONCLUSION}

The Five Principles of Peaceful Coexistence were used for decades by the Chinese authorities in an instrumental way. The historical humiliation of China by the imperialist policy of the great powers, was to be transformed into creating the Middle Kingdom a moral power in the period of its political and economic weakness. At that time, China was looking for partnerships in third world countries to promote anti-imperialist policy (Harnisch, 2016). The Five Principles of Peaceful Coexistence are still the official doctrine of the PRC's foreign policy. Chinese authorities invariably claim that non-aggression, non-interference in internal affairs, respect for territorial integrity, equality of states and peaceful cooperation 
based on the benefits of all parties are still pillars of their actions in the international relations. The example of Crimea showed, however, that they are not independent of circumstances affecting the profitability of their practical observance (MacDonald, 2016). Modern China is significantly different from that from a few decades ago. The historical burden of humiliation is being replaced by an increasing sense of strength. It is worth recalling the words of the Minister for Foreign Affairs Wang Yi, who in three words characterized China's contemporary foreign policy: confidence - resulting from strength and prosperity, backbone - resulting from national pride, and generosity - resulting from self-confidence of an old civilization (Chen, 2016).

Moscow's political move towards Beijing is to protect Russia from the negative consequences of Western sanctions imposed on it after the annexation of Crimea and military activities in Donbass (Arduino, 2017). Beijing has well interpreted this attitude of Russia, giving up criticism of its partner. China decided that this attitude could bring it a number of benefits, what actually happened. However, China will find it increasingly difficult to maintain good relations with Russia if its policy becomes more and more determined and confrontational. It will be even harder for Pekin to promote the Principles of Peaceful Coexistence in the international relations (Kiezkowa, 2016). Russia's current foreign policy harms all of these principles. This, in turn, shows that China's is ready to follow them only when it may serve its own interests. It is also highly probable that after achieving a dominant position in economic, political and military field, China will also indulge the violation of the Principles of Peaceful Coexistence. This will apply to the situation when the strategic interests of the Middle Kingdom will be at stake. Such a scenario suggests, for example, an increasingly firm attitude of China towards the countries of the South China Sea basin.

\section{REFERENCES}

Arduino, A. (2017). China's Energy Interests in Central Asia and Russia: Symbiotic distrust and striking a balance between cooperation and confrontation [In:] Wu, F., Zhang, H., eds., China's Global Quest for Resources. Energy, food and water. London-New York: Routledge.

Bitzinger, R.A. (2015). China's military buildup: regional repercussions [In:] Li, M., Kemburi, K.M., eds., China's Power and Asian Security. London-New York: Routledge.

Black, J.L. (2015). The Russian Presidency of Dmitry Medvedev, 2008-2012. The next step forward or merely a time out? London-New York: Routledge.

Chan, G. (2017). China and global governance: evolving approaches [In:] Boon, H.T., ed., Chinese Foreign Policy Under Xi. London-New York: Routledge.

Chen, Y. (2016). Philosophy, identity, and role theory with "Chinese characteristics" [In:] Harnisch, S., Bersick, S., Gottwald, J-C., eds., China's International Roles. London-New York: Routledge.

Chenoy, A.M., Kumar, R. (2017). Re-emerging Russia. Structures, Institutions and Processes. New York: Palgrave Macmillan.

Copper, J.F. (2016). China's Foreign Aid and Investment Diplomacy. Vol. III. Strategy Beyond Asia and Challenges to the United States and the International Order. New York: Palgrave Macmillan.

Donaldson, R.H., Nogee, J.L., Nadkarni, V. (2015). The Foreign Policy of Russia. Changing Systems, Enduring Interests. Fifth Edition. London-New York: Routledge. 
Duggan, N. (2016). China's Changing Role in its all-weather friendship with Africa [In:] Harnisch, S., Bersick, S., Gottwald, J.C., eds., China's International Roles, London-New York: Routledge.

Fernandes, S. (2014). Putin's Foreign Policy towards Europe: Evolving Trends of an (Un)Avoidable Relationship [In:] Kanet, R.E., Piet, R., eds., Shifting Priorities in Russia's Foreign and Security Policy. London-New York: Routledge.

Harnisch, S. (2016). China's historical self and its international role [In:] Harnisch, S., Bersick, S., Gottwald, J-C., eds., China's International Roles. London-New York: Routledge.

Higgins, A. (2017). China and Russia Hold First Joint Naval Drill in the Baltic Sea, 25 July [Access: 22.07.2018]. Access on the internet: https://www.nytimes.com/2017/07/25/world/ europe/china-russia-baltic-navy-exercises.html.

Junbo, J., Zhimin, Ch. (2016). China and the EU in the UN [In:] Wang, J., Song, W., eds., China, the European Union, and the International Politics of Global Governance. New York: Palgrave Macmillan.

Kai, J. (2017). Rising China in a Changing World. Power Transition and Global Leadership. New York: Palgrave Macmillan.

Kiezkowa, A. (2016). Chinese regionalism: balancing and constraint in the Shanghai Cooperation Organisation [In:] Ping, J.H., McCormick, B., eds., China's Strategic Priorities. LondonNew York: Routledge.

Lanteigne, M. (2016). Chinese Foreign Policy. An Introduction. Third Edition. London-New York: Routledge.

Leichtova, M. (2016). Misunderstanding Russia. Russian Foreign Policy and the West. LondonNew York: Routledge.

Lin, J., Singer, P.W. (2014). The Bear And Dragon Goes To Sea Again: Russian And Chinese Navies' Joint Sea Drill 2014, 28 May [Access: 22.07.2018]. Access on the internet: https://www.popsci.com/blog-network/eastern-arsenal/bear-and-dragon-goes-sea-again-russian-and-chinese-navies\%E2\%80\%99-joint-sea

Macaskill, E. (2014). Russian troops removing ID markings 'gross violation', "The Guardian" 6 March [Access: 22.07.2018]. Access on the internet: https://www.theguardian. com/news/defence-and-security-blog/2014/mar/06/ukraine-gross-violation-russian-troops

MacDonald, A. (2016). Access, Assurance and Acceptance [In:] Cao, H., Paltiel, J., eds., Facing China as a New Global Superpower. Domestic and International Dynamics from a Multidisciplinary Angle. Singapore: Springer.

Nathan, A.J. Principles of China's Foreign Policy [Access: 20.07.2018]. Access on the internet: http://afe.easia.columbia.edu/special/china_1950_forpol_principles.htm

Perovic, J. (2009). Introduction: Russian energy power, domestic and international dimensions [In:] Perovic, J., Orttung, R.W., Wenger, A., eds., Russian Energy Power and International Relations. London-New York: Routledge.

Reuters. (2014). China urges restraint in Ukraine, avoids comment on Crimea vote, 17 March [Access: 22.07.2018]. Access on the internet: https://www.ndtv.com/world-news/china-urgesrestraint-in-ukraine-avoids-comment-on-crimea-vote-554180

Snetkov, A. (2017). Russia's Security Policy under Putin. A critical Perspective, London-New York: Routledge.

Tharoor, I. (2015). Don't forget how the Soviet Union saved the world from Hitler. "The Washington Post" 8 May [Access: 20.07.2018]. Access on the internet: https://www.washingtonpost.com/news/worldviews/wp/2015/05/08/dont-forget-how-the-soviet-union-saved-theworld-from-hitler/?utm_term $=.23 f 58789109 \mathrm{~b}$ 
Wan, M. (2016). The Asian Infrastructure Investment Bank. The Construction of Power and the Struggle for the East Asian International Order. New York: Palgrave Macmillan.

Zhou, L. (2017). Chinas role in Syria's endless civil war. "South China Morning Post" 7 April [Access: 20.07.2018]. Acces on the internet: http://www.scmp.com/news/china/diplomacy-defence/article/2085779/backgrounder-chinas-role-syrias-endless-civil-war

DOI: $10.7862 /$ rz.2019.hss.3

The text was submitted to the editorial office: August 2018.

The text was accepted for publication: March 2019. 